\title{
FORMATION OF COMPLETE REFLEX CONSTRUCTIONS OF FUTURE PEDAGOGUE IN THE EDUCATIONAL ENVIRONMENT OF HIGHER EDUCATION
}

\author{
VIKTORIYA ZHELANOVA
}

\begin{abstract}
The article substantiates the relevance and expediency of the implementation of reflexively oriented education of a future teacher in a modern institution of higher education. The essence of reflexive constructs of the future teacher as unity of reflexive competence and reflexively deterministic constructs is revealed. The reflexive competence of the future teacher is defined as professional-personal metaquality and is represented in two planes: 1) as an independent construct; 2) as a determinant, which determines the development of reflexively saturated constructs. In the context of reflexive determination, the motivational, semantic and subjective fields of personality are presented. The directions of the process of transformation of components of reflexive competence, as well as motives, meanings, professional subjectivity in the plane of their reflexive determination are revealed. The phenomenon of the educational environment of the institution of higher education is analyzed and attention is focused on its reflexive orientation. The logic and peculiarities of the formation of reflexive constructs of the future teacher in accordance with the phases of the environment (adaptation to the environment, the active reproduction of the environment by students, the active influence of students on the environment and the independent creation of the environment) are highlighted.
\end{abstract}

Keywords: reflexive competence, reflexive determination, motivation, semantic sphere, professional subjectivity of the future teacher, educational environment of higher education institution, creation environment.

\section{INTRODUCTION}

The most important trend of modern higher education in Ukraine is its reflective orientation (I. Bech, N. Bibik, O. Savchenko). I. Stetsenko, I. Kolesnikova believed, that the leading paradigm of modern education and scientific approaches is synthesized in a reflexive educational paradigm that aims to create a certain environment for self-knowledge, self-awareness and self-revelation of the personality of the future specialist. Its purpose is to form future specialist reflexive constructs. Also known is the position regarding the justification of the idea that almost reflexive processes permeate teacher professional activity. It acquires a new, pedagogically directed content and this is what it is appropriate to call it a pedagogical (Y. Kulyutkin, G. Sukhobska) [6]. Humanization process being implemented at all levels of modern education requires increased reflection in the knowledge of 
himself and high sense of responsibility for another person. This idea gave particular relevance to pedagogical reflection.

The phenomenon of pedagogical reflection is quite thorough research in pedagogy and psychology (I. Bekh, A. Bizyayeva, N. Kuzmina, A. Markova, A. Rean, S. Sysoyeva). However, in the context of the problem of this article, we are based on a scientific direction in which the interpretation of pedagogical reflection is connected with the teacher's reflexive competence $(\mathrm{O}$. Anisimov, O. Bodalov, A. Derkach, Y. Kusheverska, O. Polishchuk, I. Ulyanich), as well as on the concept of reflective determination of activity and personality of A. Karpov [4].

We consider the recognition of the dominant role of reflective competence is absolutely justified, as we face the problem of shortage of students professional quality, resulting in the lack of understanding of the causes of various educational phenomena, perceptual illiteracy in stereotyping relationships with children in the invasion of their I-space, in the unpredictability of professional activity. In studies A. Bizyayeva, even appeared the term "deficit of reflection" [2].

It should be noted that taking into account the current trends in the implementation of the environment of oriented education (M. Bratko, Y. Manuylov, S. Sergeev), the plane of formation of reflexive constructs of the future teacher is the educational environment of higher education institution. Thus relevance of the submitted article is obvious.

\section{ANALYSIS AND DisCUSSION}

In previous studies, we have substantiated the conceptual model of reflexive constructs of the future teacher, which reflects the results-oriented aspects of vocational training and consists of two blocks [3]. The first block presents reflexive competence, which is thought to be sufficiently new concept, which was formed in acmeology and is considered from the standpoint of methodology (O. Anisimov) and reflexive psychology(I. Semenov, S. Stepanov) as a professional quality of the individual, the essence of which is the availability of readiness and professional reflection ability. The S. Stepanov's approach is widely used, according to which reflexive competence is defined as the professional quality of the individual, which allows the most effective and adequately to carry out reflexive processes, the implementation of reflexive ability, which provides the process of development and self-development, promotes creative approach to professional activity, achievement of its maximum efficiency and performance [7]. Ability to reflect as a special type of analysis of their activities lies at the basis of future teacher professional competence, and the formation of reflexive competence is one of the most important directions of its preparation in higher education institution.

Taking into account the outlined scientific positions, the author's interpretation of the reflexive competence of future teachers is based on the understanding of it as a transversal meta-competence, which is an integrated characteristic of the individual, represented by a set of components adequate to the reflexive activity realized in the reflexive processes effective implementation and predetermine the successful mastery of professional activity, namely:

- motivational-value component containing motives, value orientations, setting to reflexive activity, positive, open I-concept;

- cognitive, represented by special psychological and pedagogical, differential psychological, socio-psychological, autopsychological knowledge as the theoretical basis of pedagogical reflection;

- operational-activity that contains the system of reflexive-analytical skills related to selfknowledge and understanding of another, self-assessment and evaluation of other people, independent interpretation, analysis, design and correction of pedagogical technologies and their own activities, presented by gnostic, social-perceptual, design-constructive, organizational, communicative skills.

The reflexive competence treatment as meta-competence, allowed, on the one hand, to study the phenomenon that considered as an independent construct, and on the other - as a transverse quality that determines reflexively saturated constructs of the individual. The above position enables the study of motivation, semantic and subjective sphere of individual as a reflective saturated and reflexive determined. 
Let's analyze the phenomenon essence of reflexive determination, which is thoroughly considered in the A. Karpov study. The scientist proves the deterministic reflection macro functions and considers the leading among them the facilitating, inhibiting, modeling and generative functions. Their totality and specificity are invariant with respect to those activity and personal structures that are influenced by reflection. These functions are realized in two plans: situational and suprasituational. In the first case, the action of these functions equivalent role determination reflection on the parameters and characteristics of activity and the degree of personal qualities manifestation. In the second - their action means that reflection manifests itself not only in the activity and functioning of the individual, but also forms them [4]. It should be noted that both of these positions are important in the format of our study. We believe, that the most "reflexive" the motivation and sense sphere of the individual and its subjectivity. Consider them in the plane of reflective determination.

Motivational sphere is rightly considered the core of the personality. There are a number of scientific positions on the interpretation of the nature, content and structure of these phenomena, and the means of their formation. Consequently, we can state certain directions in determining the essence of motives and considering them as needs (L. Bozhovich, O. Kovalev, K. Platonov, L. Stolyarenko); as a goal (O. Leontiev); as an incentive (V. Merlin, M. Jacobson); as an internal position of the person (L. Bozhovych); as a certain "need state", as emotions, as an estimation (V. Aseev, A. Kovalev, P. Yakobson); as personal dispositions (D. Uznadze); as any of the root causes of activity (E. Ilyin). Taking into account the above scientific approaches, we consider it expedient to understand the motive as a complex hierarchical formation of the personality that integrates goals, needs, motivations, the internal position of the individual, its certain emotions, personal dispositions, and evaluation attitudes.

The most "reflexive" is the interpretation of the motive as an internal position, as an installation, as a goal, since "shifting the motive to the goal" is associated with the reflection of arbitrary human behavior.

Wider than the motive is the motivation concept. Research motivation of future teachers takes into account the essence of the "motivational syndrome" concept (N. Bakshayeva), characterized by a motivational system that displays the interaction and transformation process of the individual. The leading forms of "motivational syndrome" are cognitive and professional motives, which respectively constitute "cognitive motivational syndrome" and "professional motivational syndrome", which are manifested and formed in the educational activity of the subject, on the one hand, as relatively independent systems of motives, and from another - how the components of "general motivational syndrome" are interrelated in their development [1].

The motivation of the individual interconnected and interdependent with its semantic field according to research of D. Leontiev, Z. Rzhevska-Stefan, B. Sosnovsky and others.

In our study format, the meanings of personality are considered as a reflexively deterministic construct, which is an element of the target orientation of the future teacher professional training. This approach seems reasonable to us, since, as well as reflection, meanings are dominant in the regulation of human life. We insist that the semantic scope of future teachers is a set of semantic entities and relationships between them, providing the semantic regulation of the profession. Under the terms of the structural and functional approach it distinguishes situational (semantic unit) and stable (meaning dispositions, personal values) semantic entity.

In addition to the mentioned reflective deterministic constructs of the future teacher, attention should be paid to his professional subjectivity, since in the context of the current process of higher education orientation on the "personal dimension" the "subjective" qualities of the individual acquire an increasing importance that predetermine continuous gradual self-development, creative selfdetermination and productive self-realization of the future specialist in the profession.

We regard the professional subject of the future teacher as an integrated professionally important quality, which ensures the purposeful and optimal realization of their personal resources for solving professional and vital tasks and manifests itself in the quest for self-realization, that is, to selfactualization. The structure of professional subjectivity contains a subject's professional position, pedagogical activity, subject experience, ability to reflect, anticipation. 
Therefore, we have highlighted the essence of reflective constructs a future teacher. Next, consider the logic of their transformation.

Taking into account the above structure of reflexive competence, we note that the motivational aspects of this phenomenon will be transformed as follows: motives, needs for reflexive activity, reflexive setting, value attitude to reflection.

The development of cognitive and operational-activity components of reflection, respectively, associated with the change of knowledge and skills from those that reflect the personal, intellectual type of reflection - to the knowledge and skills relating to cooperative and communicative reflection. That is, the reflection directed "on itself" is expanded by the reflection which directed "on others".

Finally, on an occasional basis, reflection develops from retrospective and situational - to a promising one, which is associated with anticipatic processes.

Thus, the development of reflective future teachers competence is a process of gradual development components reflective competence towards their complications and the spread range implementation of various types of educational reflection synthesized in contextual reflection.

The process of transformation of cognitive motives in going professional as a process of gradual replacement of cognitive motives professional within the "general motivational syndrome" based object changes its actual activities "by-product" and a single-step motivational mastery of the general scheme of the process.

It should be noted that the process of transformation of motives is associated with the general logic of constructing a motivational process that is a staged phenomenon, that is, a sequence of stages, each of which performs a certain function and, in accordance with the interpretation of A. Faizullaev represented by such stages.

1. The emergence of awareness and motivation. This phase is associated with the emergence of incentives, sources of activity. However, as we have already noted, motivation is not a motive. The first step in the formation of a real motive is his awareness. That's it - the key point of this stage.

2. Adoption of the motive. The leading content of this stage is the identification of incentives with the motivational and semantic entities of the individual, that is, the realization of the meaningful function of motives.

3. Implementation of the motive. The content of this phase is associated with the transformation of motives in a particular situation.

4. Fixing the motive. At this stage in the process of steady repetition of similar situations to stimulate specific needs is consolidating as a motive traits.

5. Actualization of impulses. This phase is associated with repetitive situations consistently updating and meet the relevant requirements, leading to the consolidation of a motivational tendencies as inner necessity, habit [20].

Analytical review of motivational stages of the process gives rise clarify mechanisms saturation reflective awareness, identification with certain incentives motivational personal semantic entities.

Thus, there is a clear reflective conditionality and saturation motivational aspects of personality of future teacher. They relate to the implementation of many types of pedagogical reflection, namely: personal, cooperative, communicative, situational, perspective.

The semantic sphere of the future teacher in accordance with the ideas of the dynamic approach is connected with the meaningful formation, sense consciousness and phony construction in the "small dynamics" of meanings, within which there is a series of successive transformations of the components of semantic sphere, connected with the ascent of the hierarchy of intrapersonal structures. Ontologically this process represents transcendence, that is, the constant production and renewal of semantic sphere (I. Kolyesnikova) [5].

Specifies that sense-formation is identified by us with the emergence of semantic entities. At the same time, we turn to the classical "development zones" (L. Vygotsky) and the well-known psychological sequence "entry into the development zone - the zone of actual development - the zone of the nearest development - the zone of self-development", which are determinant in the trends of the 
formation of meaning. The meaningfulness and sensibility of the future teacher of the elementary classes is the verbalization of meaning and its reflection.

The dynamics of semantic generates a constant interaction between situational meaning and manifestations of those semantic structures, claiming the status of stable. The semantic personality development corresponds to logic from individual to general.

Thus, the development of the semantic sphere of the future teacher is carried out in several directions, namely: 1) the transformation of situational semantic structures (personal meaning, semantic setting, sensory-forming motives) into stable (semantic constructs, semantic disposition, personal values); 2) "sense-saturatioz" from the minimum to the maximum state on the basis of "refinement and expansion" (V. Zinchenko); 3) the hierarchy of meanings, their "crystallization" (O. Leontiev); 4) the change of dynamic semantic processes in sequence: sense formation, sense consciousness, sentiment construction.

Development of future teacher professional subjectivity is understood as a process of successive transformation components subjectivity professional future specialist, which is subjective, professional attitude, educational activity, subjective experience, ability to reflection, anticipation.

Taking into account the above-mentioned positions regarding the characteristics of the structural components of the subject's sphere of the future teacher, as well as the criteria for their formation, we will define their transformational peculiarities.

Subjective professional position is transformed from the orientation of "the result" to the orientation "on the process", on the means of conducting educational and professional activities; from the priority of personal values to the coordination of personal values with the professional and the priority of professional values; from unconscious assimilation of social norms and standards without regard to professional activity to a conscious assimilation of social norms and standards, when the subject is already determining his position towards them; from lack of initiative and responsibility to the student's initiative and responsible attitude to education. In general, the development of a subjective position is the stage of orientation, enrichment, implementation.

Educational activity is modified from the unconscious to the conscious, from situational to suprasituative, not adapted (V. Petrovsky) integrative activity (K. Abulkhanova-Slavska).

Subjective experience develops along the line: value experience, operational experience, experience of reflection, experience of the usual activation, experience of cooperation.

Anticipating is transformed from the ability to predict the results of its own activity to the ability to predict the actions of others, as well as to the ability to predict the effects of interaction with students.

Further, taking into account the essence of the reflexive constructs and the peculiarities of their transformation, we characterize the logic of their formation in the reflexively oriented educational environment of the institution of higher education as a multilevel pedagogically organized system of conditions and opportunities that contribute to the effectiveness of the process of formation of reflective constructs of the individual within certain stages of the educational environment.

The first stage of the formation of the environment (1st course of study at the institution of higher education). This period of education coincides with the phase of adaptation to the conditions of the specified environment, when the student begins to correlate their capabilities and needs with the capabilities of the environment and between them there is a contradiction. The objectives of this phase are: 1) the formation of motives for understanding the purpose of the profession in society, professional interests, professional expectations, the implementation of the incentive function of motivation; 2) the formation of reflection as a basic personal formation; 3 ) the formation of situational semantic entities, namely, personal meanings, semantic installation to future professional activities; 4) the formation of subjectivity as a personal construct, consisting in stimulating the needs in the development of its subjectivity, in self-knowledge, clarifying its subject potential.

The formation of the medium during this period is associated with the realization of objective environmental conditions, that is, with the actualization of the motivational, reflexive, semantic, subjective potential of the fundamental educational disciplines, which at this stage are "Introduction to 
the Specialty", "Pedagogy" (integrated course) , section "General Fundamentals of Pedagogy", as well as contextualization of educational material.

We offer at an early stage of education to use some form of training, which is given by the professional and personal context professional activity of future teachers. At the same time, knowledge ceases to be abstract and superimposed on the "canvas of professional activity" (terminology A. Verbitsky). Such are lectures of contextual type, non-auditory tasks of reflexive orientation (drawing "My portrait in the rays of the sun", "Self-description", auto-essay "What do I want to change in myself?"), which are based on the method of introspection (from the Latin introspecto - to look inside), which is to observe their own feelings, thoughts, that is, self-observation. Regarding the interpretation of "other", it is expedient to use the analysis of pedagogical situations, but not as an independent organizational form of contextual education, but as a method of teaching. An example can be situations-antipodes that illustrate the "positive" and "negative" teachers. In the process of analyzing such situations, students state the formation or absence of certain professional qualities of the teacher, and also correlate their "I-image" of a professional with the professional "I" of another teacher. Add that these "antipodes situation", provides students with several alternatives that opportunity to make choices based on their semantic advantage. Besides changing the options is a common mental technique (F. Vasilyuk, N. Myronenkova).

The student during this period adapts to the conditions of the educational environment, is its object, their relations in the system "environment - student" are defined as "subject-object". The environment is considered as a factor in the formation of personality; and the student - as an object that adopts this influence and begins to realize itself in the environment. The student's state of being in the environment is formed.

The second stage of the formation of the environment (II, III courses in higher education). This period coincides with the phase of the student's active reproduction of the educational environment. Student information relates a study with professional situations and uses it as a function of the means to achieving their action. Information for the student acquires a personal sense.

The objectives of this phase are as follows: 1 ) the formation of precisely professional motivation, the realization of the purpose-forming, regulatory function of the motives; 2) the formation of reflection as a significant professional quality; 3) formation of stable semantic formations, namely - fixed semantic installation; 4) formation of the primary professional subjectivity; 5) the formation of certain communicative skills that reflect the social context of the future profession.

The formation of the environment in this period is connected, as in the previous stage, with the realization of objective environmental conditions, that is, with the elucidation of the professional potential of the educational discipline "Pedagogy", namely the sections "Theory of education", "Didactics". However, special conditions are created that involve the development of special courses of a certain orientation. Such a condition within the framework of quasi-professional activity is the discipline "Theory and methodology for solving professional and pedagogical tasks", which is represented by a triad of training courses, namely: 1) "Analysis of Pedagogical Situations" (II course); 2) "Modeling of the Pedagogical Process" (III course); 3) "Designing a Pedagogical System" (IV course).

Note that in such a format pedagogical situations and tasks are used not as learning methods, but as independent organizational forms of studying context-type, which contain significant potential for introducing in the process of professional training of the teacher of primary classes of motivationstimulating, reflexive-forming, sensory-shaping, subject-forming, social professional contexts of the future specialist.

What is happening in the educational environment in the phase of its active reproduction by students? 1. "Immersion in itself" changes, "immersion in the profession". 2. There is a shift in motivation from the subject of cognitive activity to the subject of quasi-professional activity, there are precisely professional motives, the student accepts them, the motivation is already identified with the need. 3. Appealing to oneself, which was associated with personal reflection, spread intellectual reflection, as well as appeal to others, formed a communicative interpersonal, social types of pedagogical reflection. That is, the sphere of reflection becomes, in addition to self-awareness, also 
thinking and communication. Contextual reflection is already formed as a professionally significant quality of the elementary school teacher. 4. Beginning to form persistent semantic structures that become sensibleconcerned. That student is already able to make a conscious choice of semantic, but so far only in certain situations. There is disclosure, understanding of professional sense. 5 . The primary professional subjectivity of future educators is formed, which manifests itself in the emergence of supersituative activity, experience of cooperation, situational self-actualization. 6 . A student acquires certain communication models that are inherent in future professional activities in the process of implementing its social context.

Consequently, there is no doubt that the educational environment is expanding. Objective conditions are supplemented by specially created ones, which result in the growth of the immersion of the environment. That is, the student and the environment are already subjects, their relationships become "inter-subject" in the context of increasing interactivity of the environment.

The third stage of the formation of the environment (IV courses in higher education). During this period, the student actually occupies the position of a specialist and his activities become content, forms and technologies professional. The tasks of this stage are as follows: 1) consolidation and updating of professional motives, implementation of corrective motive functions; 2) the formation of reflexive competence as a significant professional quality; 3) realization of the deterministic function of reflection; 4) mastering all components of the integral mechanism of reflection; 5) the formation of stable professional semantic entities, namely - semantic disposition, the implementation of the process of sensual construction; 6) the formation of a professional subjectivity; 7) the formation of a system of skills that reflects the social context of the future profession.

Within this period, as in the previous stages, both objective and specially created conditions of the reflection-context environment are realized. A leading feature of the environment is the priority of group forms of students' work, based on discussions, dialogue, polylogue. This form of organization of students together promotes professional contexts future specialist. During this period, pedagogical reflection already acquires the status of reflexive competence as a holistic, integrated professionalpersonal quality, as well as its determinatory functions are implemented in relation to the motivational, semantic, and subject areas of future educators. We insist that effective within the educational and professional activities are not just a form of group work, and those that can realize the whole cycle reflexive process. Such, for example, is the technology for the formation of the reflexive activity of the Dutch scientist F. Korthagen [9], reflexion engineering "reflexive team" (the idea of the Norwegian specialist Tom Anderson) [8].

We state changes that coincide with the phase of active influence of students on the environment and independent creation of it. 1 . There is a reflexive and semantic immersion of a student in the future profession. 2. The process of transformation of cognitive motives into a professional is determined by the shift in motivation from the subject of quasi-professional activity to the subject of professional activity, and the consolidation and updating of the incentive takes place. 3. Reflexive processes are spreading by cooperative reflection, that is, all the leading types of pedagogical reflection are already realized. It becomes a complex, integrated quality of personality, namely, the context reflection, which is the basis of reflexive competence. 4. The determinational functions of reflection concerning the motivational, semantic, and subject areas of the future specialist are actively implemented. 5. A stable semantic attitude towards the future profession of a primary school teacher is supplemented by a semantic attitude to the personality of a junior pupil. Manifestations of meaning are associated with the realization of meaning during certain events, as well as the emergence of a "semantic trace" (I. Abakumova). 6. A student is already aimed at self-actualization and self-actualization in the future profession, there is a true awareness of the subject's professional position. 7. Student acquires models of dialogically-directional discussion. 


\section{CONCLUSIONS}

Thus, the article presents the essence and structure of the reflective constructs of the future teacher. Represented reflexive competence, as an end-to-end metaquality, which is an integrated personality trait, represented by a set of components, adequate to reflexive activity, realized in the effective implementation of reflexive processes and predetermine the successful mastery of professional activity. Such components are: motivational-value, cognitive, operational-activity.

Proved that self-reflective competence is reflective construct and determinant that leads to the development of reflexive saturated constructs that are motivational, semantic sphere of the individual, his professional subjectivity.

The plane of formation of reflexive constructs of the future teacher is the educational environment of higher education institution as a multilevel pedagogically organized system of conditions and opportunities that contribute to the effectiveness of the process of formation of reflective constructs of the individual within certain stages of the environment (adaptation to the conditions of the indicated medium, the active reproduction of the environment by students, the active influence of students on environment and independent creation of it). The formation of the medium at all stages is associated with the realization of objective and specially created external and internal environment conditions that are aimed at forming reflexive competence and reflexively determined constructs of the personality of the future specialist, namely, motivation, meanings, and professional subjectivity. The criteria for the quality of the environment are immersion, presence, interactivity as the leading characteristics of a reflexively oriented educational environment. Given the complexity and multidimensionality of the presented problem, there is an obvious need for substantiation and development of a coherent technology for the formation of reflexive constructs of the future teacher.

\section{REFERENCES}

[1] Bakshaeva N.A., Verbitsky A.A. Psychology of Student Motivation. Logos, Moscow, 2006. (in Russian)

[2] Bizyaeva A.A. Psychology of a Thinking Teacher: Pedagogical Reflection. PSPU named after S.M. Kirov, Pskov, 2004. (in Russian)

[3] Zhelanova V.V. The Model of Reflexive Constructs of Future Primary School Teachers as a Target Guideline of Context-Based Learning Technology. "The Scientific Opinion", 10 (2013). (in Russian)

[4] Karpov A.V. Reflexive Determination of Activity and Personality. RAO, Moscow, 2012. (in Russian)

[5] Kolesnikova I.Ye. Mechanism of personality sense in ontogenesis: morphogenetic and ontological context: monograph. Dissertation for the degree of the Candidate of Psychological Sciences: 09.00.04. Kyiv, 2011 (in Ukrainian)

[6] Kulyutkina Yu.N., Sukhobska G.S. (Eds.) Modeling of Pedagogical Situations: Problems of Improving the Quality and Effectiveness of General Pedagogical Training. Pedagogika, Moskow, 1981. (in Russian)

[7] Stepanov S. Y. Acmeological Paradoxes. Acmeology, 1 (1997), 11-17. (in Russian)

[8] Tomashek N. System Coaching: a Goal-Oriented Approach in Counseling. Gumanitarnyj tsentr, Kharkiv, 2008. (in Russian)

[9] Korthagen F., Vasalos A. Levels in reflection: core reflection as a means to enhance professional growth. Teachers and Teaching: theory and practice, 11 (1) (2005), 47-71. doi: 10.1080/1354060042000337093

Address: Viktoriya Zhelanova, Borys Grinchenko Kyiv University, 18/2, Bulvarno-Kudriavska Str., Kyiv, 04053, Ukraine.

E-mail: vic.zhelanova@gmail.com

Received: 17.01.2019; revised: 04.03.2019. 
Желанова Вікторія. Формування сукупності рефлексивних конструктів майбутнього педагога в освітньому середовищі закладу вищої освіти. Журнал Прикарпатського університету імені Василя Стефаника, 6 (1) (2019), 28-36.

У статті обгрунтовано актуальність і доцільність впровадження рефлексивно зорієнтованої освіти майбутнього педагога в сучасному закладі вищої освіти. Розкрито сутність рефлексивних конструктів майбутнього педагога як єдності рефлексивної компетентності та рефлексивно детермінованих конструктів. Рефлексивну компетентність майбутнього педагога визначено як професійно-особистісну метаякість і репрезентовано у двох пдощинах: 1) як самостійний конструкт; 2) як детермінанту, що зумовлюе розвиток рефлексивно насичених конструктів. У контексті рефлексивної детермінації представлено мотиваційну, смислову та суб'єктну сфери особистості. Розкрито напрями процесу трансформації складників рефлексивної компетентності, а також мотивів, смислів, професійної суб'єктності у площині їх рефлексивної детермінації. Проаналізовано феномен освітнього середовища закладу вищої освіти й зосереджено увагу на його рефлексивній орієнтації. Висвітлено логіку та особливості формування рефлексивних конструктів майбутнього педагога суголосно етапам середовищеутворення (адаптація до умов середовища; активне відтворення середовища студентами; активний вплив студентів на середовище та самостійне його створення).

Ключові слова: рефлексивна компетентність, рефлексивна детермінація, мотивація, смислова сфера, професійна суб'єктність майбутнього педагога, освітнє середовище закладу вищої освіти, середовищеутворення. 